\title{
$B R C A 1$ And $B R C A 2$ analysis of Argentinean breast/ovarian cancer patients selected for age and family history highlights a role for novel mutations of putative south-American origin
}

Angela Rosaria Solano ${ }^{1,3^{*}}$, Gitana Maria Aceto ${ }^{2}$, Dreanina Delettieres ${ }^{3}$, Serena Veschi ${ }^{4}$, Maria Isabel Neuman ${ }^{1}$, Eduardo Alonso ${ }^{5}$, Sergio Chialina ${ }^{5}$, Reinaldo Daniel Chacón ${ }^{1}$, Mariani-Costantini Renato ${ }^{2}$

and Ernesto Jorge Podestá ${ }^{1}$

\begin{abstract}
Background: The spectrum of BRCA1/2 genetic variation in breast-ovarian cancer patients has been scarcely investigated outside Europe and North America, with few reports for South America, where Amerindian founder effects and recent multiracial immigration are predicted to result in high genetic diversity. We describe here the results of BRCA1/BRCA2 germline analysis in an Argentinean series of breast/ovarian cancer patients selected for young age at diagnosis or breast/ovarian cancer family history.

Methods: The study series (134 patients) included 37 cases diagnosed within 40 years of age and no family history (any ethnicity, fully-sequenced), and 97 cases with at least 2 affected relatives (any age), of which 57 were non-Ashkenazi (fully-sequenced) and 40 Ashkenazi (tested only for the founder mutations c.66_67delAG and c.5263insC in BRCA1 and c.5946delT in BRCA2).

Discussion: We found 24 deleterious mutations (BRCA1:16; BRCA2: 8) in 38/134 (28.3\%) patients, of which 6/37 (16.2\%) within the young age group, 15/57 (26.3\%) within the non-Ahkenazi positive for family history; and 17/40 (42.5\%) within the Ashkenazi. Seven pathogenetic mutations were novel, five in BRCA1: c.1502_1505delAATT, c.2626_2627delAA c.2686delA, c.2728 C > T, c.3758_3759delCT, two in BRCA2: c.7105insA, c.793 + 1delG. We also detected 72 variants of which 54 previously reported and 17 novel, 33 detected in an individual patient. Four missense variants of unknown clinical significance, identified in 5 patients, are predicted to affect protein function. While global and European variants contributed near $45 \%$ of the detected BRCA1/2 variation, the significant fraction of new variants $(25 / 96,26 \%)$ suggests the presence of a South American genetic component.

This study, the first conducted in Argentinean patients, highlights a significant impact of novel BRCA1/2 mutations and genetic variants, which may be regarded as putatively South American, and confirms the important role of founder BRCA1 and BRCA2 mutations in Argentinean Ashkenazi Jews.
\end{abstract}

Keywords: Argentina, early onset breast cancer, BRCA1/BRCA2, Germline mutations, Genetic variants, Familial breast cancer, Ashkenazi, Ethnicity

\footnotetext{
* Correspondence: drsolanoangela@gmail.com

${ }^{1}$ Laboratorio HRDC, INBIOMED-CONICET, Departamento de Bioquímica

Humana, Facultad de Medicina, Universidad de Buenos Aires, Paraguay 2155

Piso 5, (C1121ABG), Buenos Aires, Argentina

${ }^{3}$ Centro de Estudios Médicos e Investigaciones Clínicas, Galván 4102,

(C1431FWO), Buenos Aires, Argentina

Full list of author information is available at the end of the article
} 


\section{Introduction}

Hereditary breast cancer accounts for $5-10 \%$ of all $\mathrm{BC}$ cases [1] and is characterized by dominant inheritance, premenopausal diagnosis, more severe course, bilaterality and frequent association with ovarian cancer (OC) [2]. The identification of the two major hereditary breast/ovarian cancer genes, BRCA1 (17q21, MIM* 113705) in 1994 [3] and BRCA2 (13q14, MIM* 600185) in 1995 [4], led to a new era in the diagnosis of inherited high predisposition to breast and ovarian cancer $[5,6]$. Breast-ovarian cancer (BOC)-causing mutations and other genetic variants are distributed along the entire coding and non-coding regions of BRCA1 and BRCA2, and more than 3400 gene variants have been described in the Breast Cancer Information Core (BIC) [7]. New variants continue to be detected worldwide, mostly in BRCA1.

The prevalences of $B R C A 1 / B R C A 2$ mutations in BOC patients with early onset (EO) and/or BOC family history (FH) appear to be similar across race/ethnicity, but there is evidence of important racial and/or geographic differences in the spectrum of $B R C A 1 / 2$ genetic variation, including pathogenic mutations and variants of uncertain significance. These differences may reflect population history and genetic drifts, and could have a significant impact on genetic counselling, genetic testing, and follow-up care [8]. A typical example is provided by the case of Ashkenazi Jews, where three founder mutations: $B R C A 1$ c.66_67delAG BRCA1 c.5263insC, and BRCA2 c.5946delT account for most of familial breast-ovarian cancer [9]. Founder BRCA1 and BRCA2 mutations in Ashkenazi Jews in Israel: frequency and differential penetrance in ovarian cancer and in breast-ovarian cancer families [10].

$B R C A 1 / 2$ mutation status in subsets of BOC patients selected for age, BOC family history and ethnicity has been scarcely investigated outside Europe and North America [5,11-15], with few reports for South America, where Native American founder effects and the complex multiracial demography of recent immigration are predicted to result in high genetic variation[16]. Indeed, recent studies point to a role of Native American ancestry in BRCA1/2 disease patterns in Central and Northern America [17-22]. Epidemiological data indicate that in Argentina BC incidence [23] and mortality rates [24] are among the highest in the world. The historical records and epidemiological and molecular studies point to variable degrees of admixture among European, mainly Spanish and Italian, and Native American components in more than 50\% of the Argentinean population [16,25]. Regarding autosomal evidence of admixture, the relative European, Native American, and West African genetic contributions to the Argentinean gene pool were estimated to be $67.55 \%, 25.9 \%$, and $6.5 \%$, respectively [7].

Our study is the first report describing BRCA1/BRCA2 gene variants in Argentinean BOC patients, and highlights a significant impact of novel mutations and genetic variants which may be regarded as putatively South American. On the other hand, we confirm the key role of founder BRCA1 and BRCA2 mutations in Argentinean Ashkenazi Jews.

\section{Methods}

The study includes 134 BOC probands selected either for age at cancer diagnosis or for family history (FH), according to the criteria listed in Table 1. The patients selected for diagnosis within 40 years of age and no BOC FH (EO patients, any ethnicity) included 37 cases (21 with BC, 13 with OC, 3 with BOC; age range 12-40 years, mean age $31.0 \pm 7.5$ years). The $\mathrm{FH}$ patients (any age, 97 cases overall), selected based on the presence of at least two BOCaffected $1^{\text {st }}$ or $2^{\text {nd }}$ degree relatives, included 57 nonAshkenazi patients (32 with BC, 18 with OC, 7 with BOC, age range $26-71$ years, mean $44.6 \pm 10.9$ years), and 40 Ashkenazi patients (32 with BC, 6 with $\mathrm{OC}$ and 2 with BOC, age range: 32-64 years, mean age $47.1 \pm 9.9$ years) (Tables 1 and 2 ). The Ashkenazi subset was tested only for the panel of the three founder Ashkenazi mutations (c.66_67delAG (reported in BIC as 185delAG), and c.5263insC (in BIC as 5382insC) in $B R C A 1$ and c.5946delT (in BIC as 6174delT) in BRCA2); all the other cases were fully sequenced.

Table 1 Inclusion criteria for the probands

\begin{tabular}{llc}
\hline Group $(\mathbf{n})$ & Criteria & Number of probands \\
\hline EO (37) & Onset of cancer $\leq 40$ years & 37 \\
Ashk-FH (40) & Onset of cancer $\leq 40$ years with family history & 12 \\
& Onset of cancer $>40$ years with family history & 28 \\
FH (57) & Onset of cancer $\leq 40$ years with family history & 31 \\
& Onset of cancer $>40$ years with family history & 26 \\
Total & & 134 \\
\hline
\end{tabular}

n: total number of probands per group. EO: Early onset; Ashk: Ashkenazi; FH: Family history, defined as: at least 2 members of $1^{\text {st }}$ or $2^{\text {nd }}$ degree with breast and/ or ovarian cancer. 
Table 2 Summary of the mutations detected

\begin{tabular}{llllll}
\hline Total patients = 134 (group) & Age at diagnosis $(\mathbf{n})$ & Family history & BRCA1 mutation (\%) & BRCA2 mutation (\%) & \% of mutated \\
\hline $37($ EO) & $\leq 40$ years (37) & No & $4(10.8)$ & $2(5.4)$ & 16.2 \\
$40($ Ashk-FH) & $\leq 40$ years (12) & Yes & $3(25.0)$ & $4(33.3)$ & 58.3 \\
& $>40$ years (28) & Yes & $6(21.4)$ & $3(14.3)$ & 35.7 \\
$57(\mathrm{FH})$ & $\leq 40$ years (31) & Yes & $3(9.7)$ & $3(9.7)$ & 19.4 \\
& $>40$ years (26) & Yes & $7(26.9)$ & $2(7.7)$ & 35.8 \\
\hline
\end{tabular}

EO: Early onset; Ashk: Ashkenazi; FH: Family History.

Total coding BRCA1-2 sequencing was performed for the patients in all groups except. the Ashkenazi patients which were tested for the panel of three mutations. (n): number of probands analyzed.

Blood samples were sent from the participating centers to the Laboratory HRDC of the Department of Biochemistry, University of Buenos Aires, and were also recruited at the Centro de Estudios Medicos e Investigaciones Clinicas (CEMIC). Study eligibility required signing an informed consent as a result of the routine procedures for genetic analysis. This study was approved by the Ethics Committee of the Sociedad Argentina de Investigación Clínica.

Genomic DNA was isolated using the QIAamp DNA blood purification kit (Qiagen, www.qiagen.com). The coding sequences and exon-intron boundaries of the BRCA1-2 genes were analyzed by amplification using polymerase chain reaction (PCR) with alternative primers to avoid false results due to polymorphisms [26,27], followed by direct sequencing of at least 55 amplicons, to ensure overlapping of the segments. Sequencing was performed using either an Applied Biosystems 3730xl DNA Analyzer or an Applied Biosystems ABI PRISM ${ }^{\circledR} 310$ Genetic Analyzer. Homozygosis (HO) was confirmed by alternative sequencing in exonic and/ or intronic regions. The three Ashkenazi mutations were tested as described [28]. Variants nomenclature follows the guidelines of the Human Genome Variation Society (HGVS). Tables provide lists including also the nomenclature of the Cancer Information Core Internet Website (BIC), April 2012.

Effects of the missense mutations that resulted not reported or recorded as clinically unknown $(\mathrm{CU})$ in the BIC were predicted by virtual analyses of functional compatibility for aminoacid changes using two programs: Align-GVGD (http://agvgd.iarc.fr/) [29] and SIFT (http://sift.bii.a-star.edu.sg/) [30].

\section{Results and discussion}

We describe for the first time in Argentina the results of $B R C A 1 / B R C A 2$ germline analysis in 134 BOC probands selected either for diagnosis within 40 years of age (37 cases) or for FH (97 cases) (Tables 1 and 2). The latter included 40 Ashkenazi patients, tested only for the three founder Ashkenazi mutations [28]. All the other cases were fully sequenced.
Overall 96 mutations and sequence variants, of which 53 in BRCA1 and 43 in BRCA2, were identified in 94/ 134 patients analyzed. Mutation types, effects, carrier frequencies, worldwide occurrences and relevant references are listed in online Additional file 1: Tables S1 and Additional file 2: Table S2. The sequence variants were classified as pathogenic based on literature data and/or when predicted to truncate/inactivate the protein product.

Among the 53 sequence variants identified in BRCA1 15 are novel and 17 clinically unknown, 14 introduce a stop codon; 22 are missense substitutions (Additional file 1: Table S1). With regard to the 43 BRCA2 mutations, 9 are novel, 17 clinically unknown, 6 introduce a stop codon; 15 are missense substitutions and one is predicted to result in an aberrant splice (Additional file 2: Table S2). The truncating mutations and the novel non-truncating variants predicted to affect the $B R C A 1$ and BRCA2 gene products are described in Table 3. Synonyms, intronic and polymorphic BRCA1 and $B R C A 2$ variants ranged from 4 to 33 per individual patients and were detected in all the 94 fully-sequenced cases (Additional file 1: Table S1 and Additional file 2: Table S2). Notably, 34 variants are listed in BIC as of clinically unknown importance, and of these 14 were identified in unique patients (Additional file 1: Table S1 and Additional file 2: Table S2).

Overall, a total of 24 bona fide pathogenetic mutations, 16 in $B R C A 1$ and 8 in $B R C A 2$, were detected in 38/134 cases (28.4\%), including: a) 6/37 (16.2\%) fullysequenced patients in the group within 40 years of age; b) $15 / 57$ (26.3\%) fully-sequenced non-Ashkenazi $\mathrm{FH}$ patients; c) $17 / 40$ (42.5\%) Ashkenazi FH patients, analyzed for the three Ashkenazi mutations only (Table 2). The pathogenetic mutations were more frequent in BRCA1 $(23 / 38,60.5 \%)$ than in BRCA2 $(15 / 38,39.5 \%)$, which is in agreement with literature data [31].

The Ashkenazi-FH patients with age $\leq 40$ years showed the highest frequency of pathogenetic $B R C A 1$ and $B R C A 2$ mutations, i.e., $58.3 \%$ (for BRCA1 16.7\% in c.66_67delAG and $8.3 \%$ in c.5263insC and 33.3\% for BRCA2 c.5946delT), in agreement with literature frequencies [28,32]. The 
Table 3 BRCA1/BRCA2 truncating mutations, novel and non-truncating variants affect the gene products

\begin{tabular}{|c|c|c|c|c|c|c|c|c|c|c|}
\hline Exon & Codon & $\begin{array}{l}\text { (HGVS) Protein } \\
\text { level }\end{array}$ & $\begin{array}{l}\text { (HGVS) DNA } \\
\text { level }\end{array}$ & $\begin{array}{l}\text { BIC DNA } \\
\text { level }\end{array}$ & $\begin{array}{l}\text { BIC } \\
\text { Status }\end{array}$ & $\begin{array}{l}\text { Carrier } \\
\text { CODE }\end{array}$ & $\begin{array}{l}\text { Index case } \\
\text { Status (age) }\end{array}$ & $\begin{array}{l}\text { Family } \\
\text { history }\end{array}$ & $\begin{array}{l}\text { Inclusion } \\
\text { Criteria }\end{array}$ & $\begin{array}{l}\text { Worldwide } \\
\text { Occurrence }\end{array}$ \\
\hline \multicolumn{11}{|c|}{$B R C A 1$} \\
\hline \multirow[t]{7}{*}{2} & E23VfsX16 & Stop cod39 & c.66_67delAG & 185delAG & $\mathrm{D}$ & AB54 & $\operatorname{Br}(37)$ & $\mathrm{Br}$ & Ashk-EO-FH & Ashkenazi \\
\hline & & & & & & $\mathrm{AB} 60$ & $\operatorname{Br}(40)$ & $\mathrm{Br}$ & Ashk-EO- & \\
\hline & & & & & & $A B 77$ & Ov (44) & $\mathrm{Br}, \mathrm{Ov}$ & FH Ashk- & \\
\hline & & & & & & AB68 & Ov (44) & $\mathrm{Br}, \mathrm{Ov}$ & FH Ashk- & \\
\hline & & & & & & $A B 76$ & $\mathrm{Br}(49)$ & $\mathrm{Br}$ & FH Ashk- & \\
\hline & & & & & & AB81 & $\operatorname{Br}(52)$ & $\mathrm{Br}$ & FH Ashk- & \\
\hline & & & & & & AB87 & Ov (60) & $\mathrm{Br}, \mathrm{Ov}$ & FH Ashk-FH & \\
\hline 2 & E23KfsX18 & Stop cod40 & c.67ins A & 186insA & $\mathrm{D}$ & AB82 & $\mathrm{Br}(34)$ & $\mathrm{Br}$ & $\mathrm{EO}-\mathrm{FH}$ & NE/ME \\
\hline 5 & C61G & p. Cys61Gly & C.181 T> G & $300 \mathrm{~T}>\mathrm{C}$ & $\mathrm{D}$ & AB75 & $\mathrm{Br}(49)$ & $\mathrm{Br}$ & $\mathrm{FH}$ & $E$ \\
\hline 5 & R71G & p. Arg71Gly & c. $211 \mathrm{~A}>\mathrm{G}$ & $330 A>G$ & $D$ & AB64 & $\mathrm{Br}(43)$ & $\mathrm{Br}$ & $\mathrm{FH}$ & $E$ \\
\hline 7 & E143X & p. Glu143Stop & c. $427 \mathrm{G}>\mathrm{T}$ & $546 \mathrm{G}>\mathrm{T}$ & $\mathrm{D}$ & AB46 & $\mathrm{Br}(33)$ & $\begin{array}{l}\mathrm{Br}, \mathrm{Ov}, \\
\mathrm{Pa}, \mathrm{Pr}\end{array}$ & $\mathrm{EO}-\mathrm{FH}$ & $E$ \\
\hline 11 & S267KfsX19 & Stop cod285 & c.797_798delTT & 916delTT & $\mathrm{D}$ & AB36 & $\mathrm{Br}-\mathrm{Ov}(46)$ & $\mathrm{Br}$ & $\mathrm{FH}$ & C, L-A E, N-A \\
\hline 11 & $\mathrm{~K} 501 \mathrm{Kfs} 30$ & Stop cod530 & c.1502_1505delAATT & 1621delAATT & NR & AB20 & $\mathrm{Br}(32)$ & No & EO & Argentina \\
\hline 11 & R504VfsX28 & Stop cod531 & c.1510delC & 1629delC & $\mathrm{D}$ & $\mathrm{AB} 40$ & $\mathrm{Br}(30)$ & $\mathrm{Br}$ & $\mathrm{EO}-\mathrm{FH}$ & $E$ \\
\hline 11 & E836GfsX2 & Stop cod837 & c.507_2508delAA & 2626delAA & NR & AB67 & $\mathrm{Br}(50)$ & $\mathrm{Br}$ & $\mathrm{FH}$ & Argentina \\
\hline 11 & S896Vfs 104 & Stop cod999 & c.2686delA & 2805delA & NR & AB85 & $\mathrm{Br}(55)$ & $\mathrm{Br}$ & $\mathrm{FH}$ & Argentina \\
\hline 11 & Q910X & p. Gln910Stop & c. 2728 C > T & $2847 C>T$ & NR & AB84 & Ov (55) & $\begin{array}{l}\mathrm{Br}, \mathrm{Ov}, \\
\text { Co }\end{array}$ & $\mathrm{FH}$ & Argentina \\
\hline 11 & R1203X & p. Arg1203Stop & c.3607C $>$ T & $3726 C>T$ & $\mathrm{D}$ & AB8 & Ov (25) & No & EO & C, L-A \\
\hline 11 & E1210RfsX8 & Stop cod1218 & c.3627insA & 3746insA & $\mathrm{D}$ & AB21 & Br-Ov (33) & No & $\mathrm{EO}$ & $C, L-A, A s$ \\
\hline 11 & S1253X & p. Ser1253Stop & c.3758_3759delCT & 3877delCT & NR & AB17 & $\mathrm{Br}(31)$ & No & EO & Argentina \\
\hline 17 & T1677lfsX2 & Stop cod1678 & c.5030_5033delCTAA & 5149delCTAA & $\mathrm{D}$ & $A B 79$ & $\operatorname{Br}(51)^{*}$ & $\begin{array}{l}\mathrm{Br}, \mathrm{Ov}, \\
\mathrm{Pa}, \mathrm{Pr}\end{array}$ & $\mathrm{FH}$ & $E$ \\
\hline \multirow[t]{2}{*}{20} & S1755PfsX75 & Stop cod1829 & c.5263insC & 5382insC & $\mathrm{D}$ & AB55 & $\mathrm{Br}(49)$ & $\mathrm{Br}$ & Ashk-FH & E, Ashkenazi \\
\hline & & & & & & AB97 & $\operatorname{Br}(38)$ & $\mathrm{Br}$ & & \\
\hline \multicolumn{11}{|c|}{$B R C A 2$} \\
\hline 9 & - & Splice defect & c.793 + 1delG & IVS9 + 1delG & NR & AB99 & $\mathrm{Br}(31)$ & $\mathrm{Br}$ & EO-FH & Argentina \\
\hline 11 & N955KfsX5 & Stop cod959 & c.2808_2811delACAA & 3036delACAA & $\mathrm{D}$ & $A B 78$ & $\mathrm{Br}(50)$ & $\mathrm{Br}$ & $\mathrm{FH}$ & $E, L-A$ \\
\hline \multirow[t]{8}{*}{11} & S1982RfsX22 & Stop cod2003 & c.5946delT & 6174delT & $\mathrm{D}$ & AB43 & $\mathrm{Br}(32)$ & Br-male & Ashk-EO-FH & Ashkenazi \\
\hline & & & & & & AB47 & $\mathrm{Br}(33)$ & Br-male & Ashk-EO- & \\
\hline & & & & & & AB69 & $\mathrm{Br} / \mathrm{Ov}(45)$ & Br-male & FH Ashk-FH & \\
\hline & & & & & & AB57 & $\mathrm{Br}(39)$ & $\mathrm{Br}, \mathrm{Pa}$ & Ashk-EO- & \\
\hline & & & & & & $A B 71$ & $\mathrm{Br}(46)$ & Ov Pr, & FH Ashk- & \\
\hline & & & & & & $A B 74$ & $\mathrm{Br}(48)$ & $\mathrm{Br}$ & FH Ashk- & \\
\hline & & & & & & AB95 & $\mathrm{Br}(36)$ & $\mathrm{Br}$ & FHAshk- & \\
\hline & & & & & & AB96 & $\operatorname{Br}(60)$ & $\mathrm{Br}$ & $\begin{array}{l}\text { EO-FH } \\
\text { Ashk-FH }\end{array}$ & \\
\hline 11 & $\mathrm{~K} 1213 \mathrm{X}$ & p. Lys1213Stop & c. $6037 \mathrm{~A}>\mathrm{T}$ & $6265 A>T$ & $\mathrm{D}$ & AB34 & $\mathrm{Br}(40)$ & No & EO & $E$ \\
\hline 11 & S1882X & p. Ser1882Stop & c. $5644 C>G$ & $5872 C>G$ & $\mathrm{D}$ & $A B 117$ & $\mathrm{Br}(50)$ & $\mathrm{Br}, \mathrm{Pr}$ & $\mathrm{FH}$ & $E$ \\
\hline 11 & Y1894X & Stop cod1894 & c.5909insA & 6137insA & $\mathrm{D}$ & AB92 & $\mathrm{Br}(31)$ & $\mathrm{Br}$ & EO-FH & $\mathrm{E}$ \\
\hline
\end{tabular}


Table 3 BRCA1/BRCA2 truncating mutations, novel and non-truncating variants affect the gene products (Continued)

\begin{tabular}{lllllllllll}
\hline 14 & E2369EfsX23 & Stop cod2391 & c.7105insA & 7333insA & NR & AB98 & Br (35) & Br & EO-FH & Argentina \\
18 & $D 2723 H$ & p. Asp2723His & c.8169 G >C & $8397 \mathrm{G}>C$ & CU & AB31 & Ov (38) & No & EO & $E$ \\
\hline
\end{tabular}

D, deleterious; CU, clinically unknown importance; NR, Not Reported in Breast Information Core database(BIC) http://research.nhgri.nih.gov/bic/ Global, as defined in BIC or when reported in at least 3 continents ethnic groups in HapMap; E, European; As, Asian; A-A African-American; L-A, Latin American; N-A, Native-American; A-C America-Caucasian; NE/ME, Near Eastern/Middle Eastern;

The DNA sequence numbering of BRCA1and BRCA2 sequence variants is based on recomendations of the Human Genome Variation Society (HGVS, translation initiation codon ATG =1) BRCA1:genomic sequence:L78833; RNA sequence: U14680; BRCA2 genomic sequence: NW_001838072; RNA sequence: NM_001838072 In bold, novel mutations not previously reported.

detection rate of bona fide pathogenetic mutations in FHnegative probands selected for age within 40 years at diagnosis was $6 / 37(16.2 \%)$. This falls within the $15-31 \%$ range reported in the literature for EO BOC with FH [33-36], but is in contrast with the lack of mutations reported in EO Chilean patients without FH [37]. The published data on the South American population $[17,37,38]$ show lower rates of mutation detection, while in agreement with results from a study in the USA [31] and a large study in high risk Hispanic family from USA [39] and also with an study of Hispanic BOC from Colombia [40]. Differences in mutation detection rates might reflect divergences in the criteria of proband selection and in the methods of analysis. In fact, the other South American [37,38] reports were based on indirect mutation detection methods and not on full sequencing; in contrast, we used direct sequencing of all the amplicons along the BRCA1 and BRCA2 coding sequences and exon-intron boundaries.

It may be of interest to compare the deleterious mutation rates of the young patients with no FH (16.2\%) and of the FH cases of similar age (within 40 years) in the non-Ashkenazi and Ashkenazi groups (Table 3). Notably, a pathogenetic mutation was found in $6 / 31$ (19.4\%) nonAshkenazi FH patients within 40 years of age (mean age $35.6 \pm 4.8$ years) and in 7/12 (58.3\%) FH Ashkenazi cases within the same age cutoff (mean $35.6 \pm 2.8$ years). The recurrent Ashkenazi mutations were never detected in non-Ashkenazi probands. BRCA1 c.66_67delAG, BRCA1 c.5263insC and BRCA2 c.5946delT were found in 7 (17.5\%), 2 (5\%) and 8 (20\%) Ashkenazi probands, respectively. Interestingly, $B R C A 2$ c.5946delT was also found in a non-Ashkenazi $\mathrm{FH}$ patient who could recall a great grand mother of Ashkenazi origin. Conversely, only a non-Ashkenazi pathogenetic mutation (Asp2723His in $B R C A 2)$ was detected in one of 4 patients of Ashkenazi origin included in the subset selected for early diagnosis and no FH. This supports the full sequencing of EO Ashkenazi patients with no BOC FH.

With regard to disease association, the pathogenetic mutations in BRCA1 occurred in 16/88 BC cases (18.2\%), $5 / 24$ OC cases (20.8\%) and $2 / 22$ BOC cases (9.1\%), those in BRCA2 in 13/88 BC cases (14.8\%), 1/24 OC cases (4.2\%) and $1 / 22$ BOC cases (4.5\%). As expected, OC was more frequent in $B R C A 1$ carriers $(21.7 \%$ vs $6.7 \%)$, and $B C$ in $B R C A 2$ carriers $(86.6 \%$ vs $65.2 \%)$ [30].
Seven pathogenic mutations $(18.4 \%$ of all the mutations detected) were putatively novel: 5 in BRCA1 (21.7\% for this gene), all with frameshifts generating stop codons in exon 11, and 2 in BRCA2 (13.3\% for this gene), one with a frameshift at nt 2369, exon 14 (c7333 insA), the other (c.793+1delG) affecting the donor splicing site nucleotide at IVS +1 delG in intron 9 (Table 3).

The frequency of the common non-pathogenic variants and synonyms was in agreement with that reported in the BIC. The mutations reported in BIC as $\mathrm{CU}$ that we detected in multiple patients as homozygous (in parenthesis number of cases) and/or in association with deleterious mutations, such as p. Gln356Arg, IVS7 $+36 \mathrm{C}>\mathrm{T}$, IVS7 + 41 C > T, IVS14-63 C > G, and IVS18 + 66 G > A in BRCA1 and p. Val2171Val (9), p. Ala2466Val (4), IVS8 + $56 \mathrm{C}>\mathrm{T}$, IVS9 + 65delT, IVS10 + 12delT, and IVS11 + 80 delTTAA (1) in BRCA2 most probably represent nonpathogenic variants. Furthermore, based on prediction programs, homozygous status, detection in multiple unrelated patients and/or association with pathogenic mutations, 10 variants found in the present study and not reported in the BIC can be considered non pathogenic. These include p. Val122Asp, p. Gln139Lys, IVS7 + $38 \mathrm{~T}>\mathrm{C}$, IVS7 + 49 del $15 \mathrm{bp}$, in BRCA1 and c*110 A > C at 3'UTR in BRCA2 (two other novel BRCA2 variants, i.e., IVS4 + $246 \mathrm{G}>\mathrm{C}$ and IVS4 + 364delT, located far from the end of the exon 4 are reported here only as heterozygosity markers).

Five of the 28 missense variants (Table 4) (i.e., p. Arg7Cys, p. Cys61Gly, p. Arg71Gly, p. Tyr179Cys, and p. Met1652Thr in BRCA1, p. Asp2723His in BRCA2) were predicted to have an impact on protein structure upon evaluation by SIFT and GVGD (Table 4). BRCA1 p. Arg7Cys, differently from the other non-conservative variants, has a rather low prediction score and was found in two cases. The high prediction values for BRCA1 p. Cys61Gly and BRCA1 p. Arg71gly agree with their previously reported pathogenicity [41,42] (Table 4). Few reported data are available for $B R C A 2 \mathrm{p}$. Asp2723His [43]. $B R C A 1$ p. Met1652Thr, located in the BRCT tandem repeat region is predicted to result in a large volume change in rigid neighbourhood [44] but structural and functional assays show normal peptide binding specificity and transcriptional activity [45]. Tyr179Cys is also located in a highly conserved region and is listed as clinically 
Table 4 BRCA1/2 missense variants identified in 94 (non Askenazi) Argentinean breast/ovarian cancer cases

\begin{tabular}{|c|c|c|c|c|c|c|c|}
\hline \multirow{2}{*}{\multicolumn{2}{|c|}{$\begin{array}{l}\text { HGVS : Protein: DNA } \\
B R C A 1\end{array}$}} & \multirow[t]{2}{*}{ BIC: Status } & \multirow[t]{2}{*}{$N^{\circ}$ Carrier (\%) } & \multirow[t]{2}{*}{ Co-occurrence with deleterious } & \multicolumn{2}{|c|}{ Prediction SIFT GVGD grade } & \multirow[t]{2}{*}{ refSNP } \\
\hline & & & & & & & \\
\hline p. Arg7Cys & c. $19 \mathrm{C}>\mathrm{T}$ & $\mathrm{CU}$ & $2(1.1)$ & - & NT & $\mathrm{C} 15$ & rs144792613 \\
\hline p. Cys61Gly & c.181 T>G & D & $1(1.1)$ & - & NT & $\mathrm{C} 65$ & - \\
\hline p. Arg71Gly & c. $211 \mathrm{~A}>\mathrm{G}$ & D & $1(1.1)$ & - & NT & $\mathrm{C} 65$ & - \\
\hline p. Val122Asp & c.365 T>A & NR & $5(5.3)$ & $B R C A 2$ & $\mathrm{~T}$ & $\mathrm{CO}$ & - \\
\hline p. Gln139Lys & c. $415 \mathrm{C}>\mathrm{A}$ & NR & $6(6.3)$ & - & $\mathrm{T}$ & $\mathrm{CO}$ & - \\
\hline p. Tyr179Cys & $c .536 \mathrm{~A}>\mathrm{G}$ & $\mathrm{CU}$ & $1(1.1)$ & BRCA1 [30] (AB80) & NT & C35 & rs56187033 \\
\hline p. Gln356Arg & c. $1067 A>G$ & $\mathrm{CU}$ & $10(10.6)$ & BRCA1/BRCA2\# & $\mathrm{T}$ & $\mathrm{CO}$ & rs1799950 \\
\hline p. Phe486Leu & C.1456 T>C & $\mathrm{CU}$ & $1(1.1)$ & BRCA1 [30] (AB80) & $\mathrm{T}$ & $\mathrm{CO}$ & rs55906931 \\
\hline p. Val525lle & c.1573 G>A & $\mathrm{CU}$ & $1(1.1)$ & - & $\mathrm{T}$ & $\mathrm{CO}$ & rs80357273 \\
\hline p. Asn550His & C. $1648 \mathrm{~A}>\mathrm{C}$ & $\mathrm{CU}$ & $1(1.1)$ & BRCA1 [30] (AB80) & NT & $\mathrm{CO}$ & rs56012641 \\
\hline p. Asp693Asn & c.2077 G > A & $\mathrm{CN}$ & $8(8.5)$ & $B R C A 1$ & $\mathrm{~T}$ & $\mathrm{CO}$ & rs4986850 \\
\hline p. Pro871Leu & c. $2612 C>T$ & $\mathrm{CN}$ & 29 (30.9) & BRCA1/BRCA2\# & $\mathrm{T}$ & $\mathrm{CO}$ & rs799917 \\
\hline p. Lys898Glu & c. $2692 A>G$ & $\mathrm{CU}$ & $1(1.1)$ & $B R C A 2$ & $\mathrm{~T}$ & $\mathrm{CO}$ & rs80357420 \\
\hline p. Met1008lle & c.3024 G > A & $\mathrm{CU}$ & $1(1.1)$ & BRCA1 [30] & $\mathrm{T}$ & $\mathrm{CO}$ & rs1800704 \\
\hline p. Glu1038Gly & c.3113 G>A & $\mathrm{CN}$ & $33(35.1)$ & BRCA1/BRCA2\# & $\mathrm{T}$ & $\mathrm{CO}$ & rs16941 \\
\hline p. Ser1040Asn & c.3119 G > A & $\mathrm{CU}$ & $1(1.1)$ & BRCA1 [31] & $\mathrm{T}$ & $\mathrm{CO}$ & rs4986852 \\
\hline p. Asp1131Glu & c. $3393 C>G$ & NR & $1(1.1)$ & $B R C A 2$ & $\mathrm{~T}$ & $\mathrm{CO}$ & - \\
\hline p. Lys1183Arg & c.3548A > G & $\mathrm{CN}$ & $34(36.2)$ & BRCA1/BRCA2\# & $\mathrm{T}$ & $\mathrm{CO}$ & rs16942 \\
\hline p. Ile1275Val & $c .3823 A>G$ & $\mathrm{CU}$ & $8(8.5)$ & - & $\mathrm{T}$ & $\mathrm{CO}$ & rs80357280 \\
\hline p. Glu1586Gly & $c .4757 A>G$ & NR & $1(1.1)$ & - & NT & $\mathrm{CO}$ & - \\
\hline p. Ser1613Gly & c. $4837 A>G$ & $\mathrm{CN}$ & 33 (35.1) & BRCA1/BRCA\# & $\mathrm{T}$ & $\mathrm{CO}$ & rs1799966 \\
\hline p. Met1652Thr & c.4955 T > C & CU & $1(1.1)$ & - & NT & $\mathrm{C} 25$ & rs80356968 \\
\hline \multicolumn{8}{|l|}{$B R C A 2$} \\
\hline p. Tyr42Cys & c. $125 \mathrm{~A}>\mathrm{G}$ & $\mathrm{CU}(\mathrm{BIC})$ & $1(1.1)$ & - & $\mathrm{T}$ & $\mathrm{CO}$ & rs4987046 \\
\hline p. Asn289His & c. $865 A>C$ & $\mathrm{CN}$ & $5(5.3)$ & $B R C A 2$ & NT & $\mathrm{CO}$ & rs766173 \\
\hline p. His372Asn & C. $1114 C>A$ & $\mathrm{CN}$ & $24(4.2)$ & BRCA1/BRCA2\# & $\mathrm{T}$ & $\mathrm{CO}$ & rs144848 \\
\hline p. Arg858lle & $c .2578 \mathrm{G}>\mathrm{T}$ & NR & $1(1.1)$ & $B R C A 2$ & $\mathrm{~T}$ & $\mathrm{CO}$ & - \\
\hline p. Asn991Asp & c. $2971 A>G$ & $\mathrm{CN}$ & $4(4.2)$ & $B R C A 2$ & $\mathrm{~T}$ & $\mathrm{CO}$ & rs1799944 \\
\hline p.Q1063K & c. $3187 C>A$ & NR & $1(1.1)$ & - & $\mathrm{T}$ & $\mathrm{CO}$ & - \\
\hline p. Asp1420Tyr & c. $4258 \mathrm{G}>\mathrm{A}$ & $\mathrm{CN}$ & $1(1.1)$ & $B R C A 2[32]$ & $\mathrm{T}$ & $\mathrm{CO}$ & rs28897727 \\
\hline p. Met1915Thr & c.5744 T>C & $\mathrm{CU}$ & $1(1.1)$ & - & $\mathrm{T}$ & $\mathrm{CO}$ & rs4987117 \\
\hline p. Ser2098Phe & c. $6749 \mathrm{C}>\mathrm{T}$ & $\mathrm{CU}$ & $1(1.1)$ & - & $\mathrm{T}$ & $\mathrm{CO}$ & rs80358867 \\
\hline p. Arg2108His & c.6323 G > A & $\mathrm{CU}$ & 1.(1.1) & - & $\mathrm{T}$ & $\mathrm{CO}$ & rs35029074 \\
\hline p. Ala2466Val & c.7397C > T & $\mathrm{CU}$ & 37 (39.4) & BRCA1/BRCA2\# & NT & $\mathrm{CO}$ & rs169547 \\
\hline p. Asn2486Lys & c.7919 T> G & NR & $1(1.1)$ & - & $\mathrm{T}$ & $\mathrm{CO}$ & - \\
\hline p. Ile2490Thr & c.7469 T>C & $\mathrm{CU}$ & $6(6.3)$ & - & NT & $\mathrm{CO}$ & rs11571707 \\
\hline p. Asp2723His & c.8167 G > C & $\mathrm{CU}$ & $1(1.1)$ & - & NT & $\mathrm{C} 65$ & rs41293511 \\
\hline p. lle3412Val & c. $10690 A>G$ & $\mathrm{CU}$ & $3(3.2)$ & - & $\mathrm{T}$ & $\mathrm{CO}$ & rs1801426 \\
\hline
\end{tabular}

NR, Not Reported CU, Clinically Unknown; CN, clinically not important, in Breast Information Core database (BIC), http://research.nhgri.nih.gov/bic/; In bold missense predict deleterious; NT, Not Tolerated; T, Tolerated; Align-GVGD grade between C0 and C65; Co-occurrence: \# two or more patients.

importance unknown (CU) in BIC. Notably BRCA1 Tyr179Cys co-occurred with two other missense mutations, i.e., Phe486Leu and Asn550His, in an FH patient affected with pagetoid $\mathrm{BC}$ (AB80). These 3 mutations, already reported to occur together, may constitute a rare haplotype [46] [brca.iarc.fr/LOVD].

In agreement with the complex population history of Argentina, the $B R C A 1 / 2$ mutations detected in this BOC 
series were associated with diverse geographic/ethnic backgrounds (Figure 1 and online Additional file 1: Table S1 and Additional file 2: Table S2). Of the 96 detected variants, $25(26 \%)$ are not reported in the BIC, in HapMap [47] and in the current literature, and are thus putatively unique for Argentina, 17 (17.7\%) were reported worldwide (at least 3 continents), 4 (4.2\%) were reported only in Latin-America. The remaining variants comprise mutations previously detected in Europe, Asia and North America. (Additional file 1: Table S1 and Additional file 2: Table S2). The putative Latin American variants include p. Ile2490Thr in BRCA2, a modestly penetrant variant that might contribute to sporadic breast cancer risk, listed as $\mathrm{CU}$ in the BIC, originally described in a Caribbean patient [48] and reported almost 100 times in the BIC, frequently associated to Latin American probands. In this line, several novel variants were previously observed in Argentina in genes related to other hereditary syndromes and might be regarded as putatively regional or influenced by founding events, [49-51]. In the present case series this mutation recurred in six cases (Table 4, Figure 1)

Two other mutations related to South American ethnicity deserve mention: 1) BRCA1 IVS7 + 37 del14bp (TTTTCTTTTTTTTT), not listed in BIC but found in 10/42 families from Uruguay (including one with a pathogenetic mutation in $B R C A 2$ ) [38], and in a patient from Chile [37]; and 2) BRCA2 IVS16-14 T > C, reported in a patient from Uruguay [38] and detected in 31 of our patients (including 4 with identified pathogenic mutations).

\section{Conclusions}

The present study is the first reporting the spectrum of $B R C A 1$ and BRCA2 mutations in an Argentinean BOC series, based on the analysis of the coding sequences and exon-intron boundaries of both genes. Given that the rates of $\mathrm{BC}$ incidence and mortality in Argentina are among the highest in the world [23,24], a better understanding of the impact of $B R C A 1 / B R C A 2$-related disease in Argentinean BOC patients is important for the implementation of prevention and/or early detection strategies. In our case series selected for early diagnosis with no $\mathrm{FH}$ or for $\mathrm{FH}$ independently of age at diagnosis, the overall detection rate of bona fide pathogenetic mutations was quite high $(38 / 134,28.3 \%)$. This could rise to $35.8 \%$ (48/134) including the missense mutations suspected to confer increasing risk of breast cancer.

Although global and European sequence variants contribute to near $45 \%$ of the detected $B R C A 1 / 2$ variation, the significant fraction of new variants putatively unique for Argentina detected in the present study might

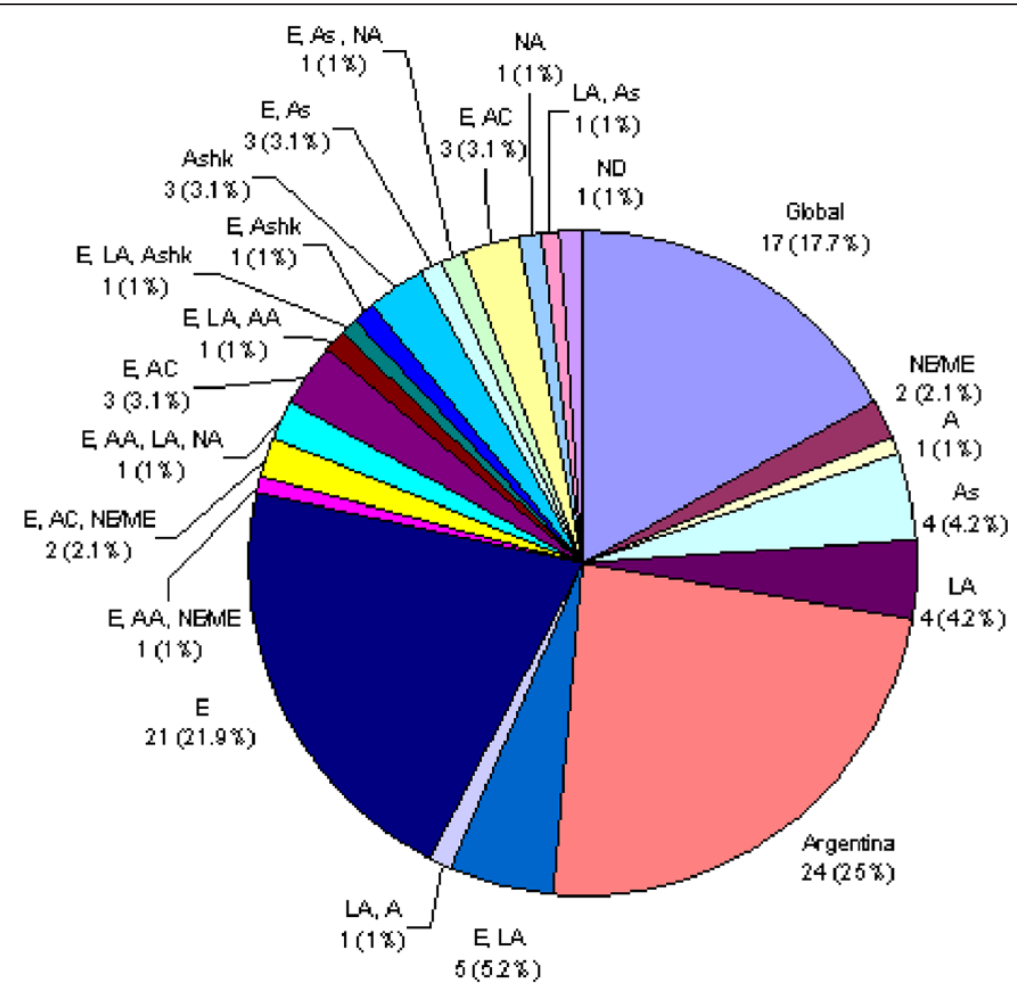

Figure 1 Worldwide occurrence of 96 BRCA1/2 variants detected in 94 non-Ashkenazi Argentinean BOC patients. Global, as defined in BIC or when reported in at least 3 continents in HapMap or in references; A, African; AA, African American; AC, American Caucasian; As, Asian; Ashk, Ashkenazi; E, European; LA, Latin American; NA, Native American; NE/ME, Near Eastern/Middle Eastern; ND, not determined. 
suggest the presence of a Native American genetic component, not yet genetically characterized, that it in recent centuries has come to admixture with alleles mostly of European origin.

\section{Additional files}

Additional file 1: Table S1: $B R C A 1$ sequence variants identified in Argentinean breast/ovarian cancer cases [38,52-57].

Additional file 2: Table S2: $B R C A 2$ sequence variants identified in Argentinean breast/ovarian cancer cases $[58,59]$.

\begin{abstract}
Abbreviations
BOC, Breast/ovarian cancer; FH, Family history; BC, Breast cancer; OC, Ovarian cancer; BIC, Breast Cancer Information Core; EO, Early onset; PCR, Polymerase chain reaction; $\mathrm{HO}$, Homozygosis; A, African; AA, American African; AC, American Caucasian; As, Asian; Ashk, Ashkenazi; E, European; LA, Latin American; NA, Native American; NE/ME, Near Eastern/Middle Eastern; ND, Not Determined; D, Deleterious; CU, Clinically Unknown; CN, Clinically No important; NR, Not reported; NT, Not tolerated; T, Tolerated; HGVS, Human Genome Variation Society.
\end{abstract}

\section{Competing interests}

The authors declare not competing interests.

\section{Author's contribution}

ARS: Contributed to study conception and design, and acquisition, analysis, and interpretation of data; and drafted and revised the manuscript critically for important intellectual content. GA: Contributed to the analysis and interpretation of data; and drafted and revised the manuscript critically for important intellectual content. DD: Contributed to sample preparation and genetic analysis, and participate in data analysis. SV: Carried out genetic analysis, data analysis coordinated data collection. MIN: Contributed to sample preparation and genetic analysis, EA: participated clinically in the diagnosis and follow up of patients and sample provision. SC: Contributed to sample preparation and provision. RDC: Critically reviewed the manuscript and participated clinically in the diagnosis and follow up of patients and sample provision and drafted the manuscript. RMC: Contributed to study conception and design, and interpretation of data; and drafted and revised the manuscript critically for important intellectual content. EJP: Contributed to study conception and design, and interpretation of data; and drafted and revised the manuscript critically for important intellectual content. All authors read and approved the final manuscript.

\section{Acknowledgements}

We thank Ulises Orlando and Paula Maloberti for their informatic scientific support. This work was supported by CONICET (112-200801-01976) http:// www.conicet.gov.ar/, Podestá; UBA (M059, 20020090200030) Podestá http:// www.uba.ar/homepage.php; FONCyT (PICT-2010-0498) Podesta, http://www. agencia.mincyt.gov.ar/. INC (Resolución Ministerial (N 148/12) http://www. msal.gov.ar/inc/novedades-proy-invest.php, Podestá, Fundacion Bunge y Born Solano/Podesta and AIRC and MIUR 60\% for activities developed at the Aging Research Center (CeSI) of the "G. d'Annunzio" University Foundation by Professor Mariani-Constantini. Collaboration between "G. d'Annunzio" University and the University of Buenos Aires is in the framework of the activities developed by CeSI as a Special Consultant of ECOSOC of the United Nations. The collaboration is supported by funds for personnel exchange, research and travel provided by the "G. d'Annunzio" University.

\section{Author details}

'Laboratorio HRDC, INBIOMED-CONICET, Departamento de Bioquímica Humana, Facultad de Medicina, Universidad de Buenos Aires, Paraguay 2155 Piso 5, (C1121ABG), Buenos Aires, Argentina. ${ }^{2}$ Department of Clinical and Experimental Sciences, "G. d'Annunzio" University, Via dei Vestini 1, 66100, Chieti, Italy. ${ }^{3}$ Centro de Estudios Médicos e Investigaciones Clínicas, Galván 4102, (C1431FWO), Buenos Aires, Argentina. ${ }^{4}$ Unit of General Pathology, Department of Medical, Oral and Biotechnological Sciences, "G. d'Annunzio" University, and Aging Research Center (CeSI), G. d'Annunzio Universith
Foundation, Via Colle dell'Ara, 66100, Chieti, Italy. ${ }^{5}$ Hospital Italiano, Virasoro 1249 (CB1921XAA), Rosario, Santa Fé, Argentina.

Received: 17 August 2012 Accepted: 30 August 2012 Published: 25 September 2012

\section{References}

1. Easton DF (2002) Familial risks of breast cancer. Breast Cancer Res 4(5):179-181

2. Claus EB, Schildkraut JM, Thompson WD, Risch NJ (1996) The genetic attributable risk of breast and ovarian cancer. Cancer 77(11):2318-2324

3. Miki Y, Swensen J, Shattuck-Eidens D, Futreal PA, Harshman K, Tavtigian S, Liu Q, Cochran C, Bennett LM, Ding W et al (1994) A strong candidate for the breast and ovarian cancer susceptibility gene BRCA1. Science 266(5182):66-71

4. Wooster R, Bignell G, Lancaster J, Swift S, Seal S, Mangion J, Collins N, Gregory S, Gumbs C, Micklem G (1995) Identification of the breast cancer susceptibility gene BRCA2. Nature 378(6559):789-792

5. Narod SA (2010) BRCA mutations in the management of breast cancer: the state of the art. Nat Rev Clin Oncol 7(12):702-707

6. Trainer AH, Lewis CR, Tucker K, Meiser B, Friedlander M, Ward RL (2010) The role of BRCA mutation testing in determining breast cancer therapy. Nat Rev Clin Oncol 7(12):708-717

7. Breast Cancer Information Core database. http://researcnhgrinihgov/bic

8. Kurian AW (2010) BRCA1 and BRCA2 mutations across race and ethnicity: distribution and clinical implications. Curr Opin Obstet Gynecol 22(1):72-78

9. Levy-Lahad E, Catane R, Eisenberg S, Kaufman B, Hornreich G, Lishinsky E, Shohat M, Weber BL, Beller U, Lahad A, Halle D (1997) Founder BRCA1 and BRCA2 mutations in Ashkenazi Jews in Israel: frequency and differential penetrance in ovarian cancer and in breast-ovarian cancer families. Am J Hum Genet 60(5):1059-1067

10. Charrow J (2004) Ashkenazi Jewish genetic disorders. Fam Cancer 3(3-4):201-206

11. Langston AA, Malone KE, Thompson JD, Daling JR, Ostrander EA (1996) BRCA1 mutations in a population-based sample of young women with breast cancer. N Engl J Med 334(3):137-142

12. de Sanjose $\mathrm{S}$, Leone $\mathrm{M}$, Berez $\mathrm{V}$, Izquierdo $\mathrm{A}$, Font $\mathrm{R}$, Brunet JM, Louat $\mathrm{T}$, Vilardell L, Borras J, Viladiu P, Bosch FX, Lenoir GM, Sinilnikova OM (2003) Prevalence of BRCA1 and BRCA2 germline mutations in young breast cancer patients: a population-based study. Int J Cancer 106(4):588-593

13. Toh GT, Kang P, Lee SS, Lee DS, Lee SY, Selamat S, Mohd Taib NA, Yoon SY, Yip CH, Teo SH (2008) BRCA1 and BRCA2 germline mutations in Malaysian women with early-onset breast cancer without a family history. PLoS One 3(4):e2024

14. Evans DG, Moran A, Hartley R, Dawson J, Bulman B, Knox F, Howell A, Lalloo $F$ (2010) Long-term outcomes of breast cancer in women aged 30 years or younger, based on family history, pathology and BRCA1/BRCA2/TP53 status. Br J Cancer 102(7):1091-1098

15. Schwartsmann G (2001) Breast cancer in South America: challenges to improve early detection and medical management of a public health problem. J Clin Oncol 19(18 Suppl):118S-124S

16. Wang S, Ray N, Rojas W, Parra MV, Bedoya G, Gallo C, Poletti G, Mazzotti G, Hill K, Hurtado AM, Camrena B, Nicolini H, Klitz W, Barrantes R, Molina JA, Freimer NB, Bortolini MC, Salzano FM, Petzl-Erler ML, Tsuneto LT, Dipierri JE, Alfaro EL, Bailliet G, Bianchi NO, Llop E, Rothhammer F, Excoffier L, RuizLinares A (2008) Geographic patterns of genome admixture in Latin American Mestizos. PLoS Genet 4(3):e1000037

17. Gomes MC, Costa MM, Borojevic R, Monteiro AN, Vieira R, Koifman S, Koifman RJ, Li S, Royer R, Zhang S, Narod SA (2007) Prevalence of BRCA1 and BRCA2 mutations in breast cancer patients from Brazil. Breast Cancer Res Treat 103(3):349-353

18. Jara L, Ampuero S, Santibanez E, Seccia L, Rodriguez J, Bustamante M, Martinez V, Catenaccio A, Lay-Son G, Blanco R, Reyes JM (2006) BRCA1 and BRCA2 mutations in a South American population. Cancer Genet Cytogenet 166(1):36-45

19. Gallardo M, Silva A, Rubio L, Alvarez C, Torrealba C, Salinas M, Tapia T, Faundez P, Palma L, Riccio ME, Paredes H, Rodriguez M, Cruz A, Rousseau C, King MC, Camus M, Alvarez M, Carvallo P (2006) Incidence of BRCA1 and BRCA2 mutations in 54 Chilean families with breast/ovarian cancer, genotype-phenotype correlations. Breast Cancer Res Treat 95(1):81-87 
20. Vidal-Millan S, Taja-Chayeb L, Gutierrez-Hernandez O, Ramirez Ugalde MT, Robles-Vidal C, Bargallo-Rocha E, Mohar-Betancourt A, Duenas-Gonzalez A (2009) Mutational analysis of BRCA1 and BRCA2 genes in Mexican breast cancer patients. Eur J Gynaecol Oncol 30(5):527-530

21. Liede A, Jack E, Hegele RA, Narod SA (2002) A BRCA1 mutation in Native North American families. Hum Mutat 19(4):460

22. Weitzel JN, Lagos VI, Herzog JS, Judkins T, Hendrickson B, Ho JS, Ricker CN, Lowstuter KJ, Blazer KR, Tomlinson G, Scholl T (2007) Evidence for common ancestral origin of a recurring BRCA1 genomic rearrangement identified in high-risk Hispanic families. Cancer Epidemiol Biomarkers Prev 16(8):1615-1620

23. Instituto Nacional del Cáncer A (2012) Manual operativo de evaluacón clínica mamaria.,

24. Matos EL LD, Zengarini N (2003) Atlas de mortalidad por cáncer en Argentina., , pp 1997-2001

25. Sala A, Penacino G, Carnese R, Corach D (1999) Reference database of hypervariable genetic markers of Argentina: application for molecular anthropology and forensic casework. Electrophoresis 20(8):1733-1739

26. Solano AR, Dourisboure RJ, Weitzel J, Podesta EJ (2002) A cautionary note: false homozygosity for BRCA2 6174delT mutation resulting from a single nucleotide polymorphism masking the wt allele. Eur J Hum Genet 10(6):395-397

27. Aceto GM, Solano AR, Neuman MI, Veschi S, Morgano A, Malatesta S, Chacon RD, Pupareli C, Lombardi M, Battista P, Marchetti A, MarianiCostantini R, Podesta EJ (2009) High-risk human papilloma virus infection, tumor pathophenotypes, and BRCA1/2 and TP53 status in juvenile breast cancer. Breast Cancer Res Treat 122(3):671-683

28. Tonin P, Weber B, Offit K, Couch F, Rebbeck TR, Neuhausen S, Godwin AK, Daly M, Wagner-Costalos J, Berman D, Grana G, Fox E, Kane MF, Kolodner RD, Krainer M, Haber DA, Struewing JP, Warner E, Rosen B, Lerman C, Peshkin B, Norton L, Serova O, Foulkes WD, Garber JE et al (1996) Frequency of recurrent BRCA1 and BRCA2 mutations in Ashkenazi Jewish breast cancer families. Nat Med 2(11):1179-1183

29. Mathe E, Olivier M, Kato S, Ishioka C, Hainaut P, Tavtigian SV (2006) Computational approaches for predicting the biological effect of p53 missense mutations: a comparison of three sequence analysis based methods. Nucleic Acids Res 34(5):1317-1325

30. Ng PC, Henikoff S (2002) Accounting for human polymorphisms predicted to affect protein function. Genome Res 12(3):436-446

31. Frank TS, Deffenbaugh AM, Reid JE, Hulick M, Ward BE, Lingenfelter B, Gumpper KL, Scholl T, Tavtigian SV, Pruss DR, Critchfield GC (2002) Clinical characteristics of individuals with germline mutations in BRCA1 and BRCA2: analysis of 10,000 individuals. J Clin Oncol 20(6):1480-1490

32. Abeliovich D, Kaduri L, Lerer I, Weinberg N, Amir G, Sagi M, Zlotogora J, Heching N, Peretz T (1997) The founder mutations 185delAG and 5382insC in BRCA1 and 6174delT in BRCA2 appear in 60\% of ovarian cancer and 30\% of early-onset breast cancer patients among Ashkenazi women. Am J Hum Genet 60(3):505-514

33. Wacholder S, Hartge P, Prentice R, Garcia-Closas M, Feigelson HS, Diver WR, Thun MJ, Cox DG, Hankinson SE, Kraft P, Rosner B, Berg CD, Brinton LA, Lissowska J, Sherman ME, Chlebowski R, Kooperberg C, Jackson RD, Buckman DW, Hui P, Pfeiffer R, Jacobs KB, Thomas GD, Hoover RN, Gail MH, Chanock SJ, Hunter DJ (2010) Performance of common genetic variants in breast-cancer risk models. N Engl J Med 362(11):986-993

34. Hutchinson L (2010) Screening: BRCA testing in women younger than 50 with triple-negative breast cancer is cost effective. Nat Rev Clin Oncol 7(11):611

35. Minami CA, Chung DU, Chang HR (2011) Management options in triplenegative breast cancer. Breast Cancer (Auckl) 5:175-199

36. Kwon JS, Gutierrez-Barrera AM, Young D, Sun CC, Daniels MS, Lu KH, Arun B (2010) Expanding the criteria for BRCA mutation testing in breast cancer survivors. J Clin Oncol 28(27):4214-4220

37. Gonzalez-Hormazabal P, Gutierrez-Enriquez S, Gaete D, Reyes JM, Peralta O, Waugh E, Gomez F, Margarit S, Bravo T, Blanco R, Diez O, Jara L (2010) Spectrum of BRCA1/2 point mutations and genomic rearrangements in high-risk breast/ovarian cancer Chilean families. Breast Cancer Res Treat 126 (3):705-716

38. Delgado L, Fernandez G, Grotiuz G, Cataldi S, Gonzalez A, Lluveras N, Heguaburu M, Fresco R, Lens D, Sabini G, Muse IM (2010) BRCA1 and BRCA2 germline mutations in Uruguayan breast and breast-ovarian cancer families.
Identification of novel mutations and unclassified variants. Breast Cancer Res Treat 128(1):211-218

39. Weitzel JN, Lagos V, Blazer KR, Nelson R, Ricker C, Herzog J, McGuire C, Neuhausen S (2005) Prevalence of BRCA mutations and founder effect in high-risk Hispanic families. Cancer Epidemiol Biomarkers Prev 14(7):1666-1671

40. Torres D, Rashid MU, Gil F, Umana A, Ramelli G, Robledo JF, Tawil M, Torregrosa L, Briceno I, Hamann U (2007) High proportion of BRCA1/2 founder mutations in Hispanic breast/ovarian cancer families from Colombia. Breast Cancer Res Treat 103(2):225-232

41. Machackova E, Foretova L, Lukesova M, Vasickova P, Navratilova M, Coene I, Pavlu H, Kosinova V, Kuklova J, Claes K (2008) Spectrum and characterisation of BRCA1 and BRCA2 deleterious mutations in high-risk Czech patients with breast and/or ovarian cancer. BMC Cancer 8:140

42. Vega A, Campos B, Bressac-De-Paillerets B, Bond PM, Janin N, Douglas FS, Domenech M, Baena M, Pericay C, Alonso C, Carracedo A, Baiget M, Diez O (2001) The R71G BRCA1 is a founder Spanish mutation and leads to aberrant splicing of the transcript. Hum Mutat 17(6):520-521

43. Goldgar DE, Easton DF, Deffenbaugh AM, Monteiro AN, Tavtigian SV, Couch FJ (2004) Integrated evaluation of DNA sequence variants of unknown clinical significance: application to BRCA1 and BRCA2. Am J Hum Genet 75(4):535-544

44. Mirkovic N, Marti-Renom MA, Weber BL, Sali A, Monteiro AN (2004) Structure-based assessment of missense mutations in human BRCA1: implications for breast and ovarian cancer predisposition. Cancer Res 64(11):3790-3797

45. Lee MS, Green R, Marsillac SM, Coquelle N, Williams RS, Yeung T, Foo D, Hau DD, Hui B, Monteiro AN, Glover JN (2010) Comprehensive analysis of missense variations in the BRCT domain of BRCA1 by structural and functional assays. Cancer Res 70(12):4880-4890

46. Tavtigian SV, Deffenbaugh AM, Yin L, Judkins T, Scholl T, Samollow PB, de Silva D, Zharkikh A, Thomas A (2006) Comprehensive statistical study of 452 BRCA1 missense substitutions with classification of eight recurrent substitutions as neutral. J Med Genet 43(4):295-305

47. Altshuler DM, Gibbs RA, Peltonen L, Altshuler DM, Gibbs RA, Peltonen L, Dermitzakis E, Schaffner SF, Yu F, Peltonen L, Dermitzakis E, Bonnen PE, Altshuler DM, Gibbs RA, de Bakker PI, Deloukas P, Gabriel SB, Gwilliam R, Hunt S, Inouye M, Jia X, Palotie A, Parkin M, Whittaker P, Yu F, Chang K, Hawes A, Lewis LR, Ren Y, Wheeler D et al (2010) Integrating common and rare genetic variation in diverse human populations. Nature 467(7311):52-58

48. Offit K, Levran O, Mullaney B, Mah K, Nafa K, Batish SD, Diotti R, Schneider H, Deffenbaugh A, Scholl T, Proud VK, Robson M, Norton L, Ellis N, Hanenberg $H$, Auerbach AD (2003) Shared genetic susceptibility to breast cancer, brain tumors, and Fanconi anemia. J Natl Cancer Inst 95(20):1548-1551

49. De Rosa M, Dourisboure RJ, Morelli G, Graziano A, Gutierrez A, Thibodeau S, Halling K, Avila KC, Duraturo F, Podesta EJ, Izzo P, Solano AR (2004) First genotype characterization of Argentinean FAP patients: identification of 14 novel APC mutations. Hum Mutat 23(5):523-524

50. Chialina SG, Fornes C, Landi C, de la Vega Elena CD, Nicolorich MV, Dourisboure RJ, Solano A, Solis EA (2006) Microsatellite instability analysis in hereditary non-polyposis colon cancer using the Bethesda consensus panel of microsatellite markers in the absence of proband normal tissue. BMC Med Genet 7:5

51. Dourisboure RJ, Belli S, Domenichini E, Podesta EJ, Eng C, Solano AR (2005) Penetrance and clinical manifestations of non-hotspot germline RET mutation, C630R, in a family with medullary thyroid carcinoma. Thyroid 15 (7):668-671

52. Ginsburg OM, Dinh NV, To TV, Quang LH, Linh ND, Duong BT, Royer R, Llacuachaqui M, Tulman A, Vichodez G, Li S, Love RR, Narod SA (2010) Family history, BRCA mutations and breast cancer in Vietnamese women. Clin Genet 80(1):89-92

53. Hamel N, Feng BJ, Foretova L, Stoppa-Lyonnet D, Narod SA, Imyanitov E, Sinilnikova O, Tihomirova L, Lubinski J, Gronwald J, Gorski B, Hansen TO, Nielsen FC, Thomassen M, Yannoukakos D, Konstantopoulou I, Zajac V, Ciernikova S, Couch FJ, Greenwood CM, Goldgar DE, Foulkes WD (2010) On the origin and diffusion of BRCA1 c.5266dupC (5382insC) in European populations. Eur J Hum Genet 19(3):300-306

54. Keshavarzi F, Javadi GR, Zeinali S (2012) BRCA1 and BRCA2 germline mutations in 85 Iranian breast cancer patients. Fam Cancer 11(1):57-67 
55. De Silva W, Karunanayake EH, Tennekoon KH, Allen M, Amarasinghe I, Angunawala P, Ziard MH (2008) Novel sequence variants and a high frequency of recurrent polymorphisms in BRCA1 gene in Sri Lankan breast cancer patients and at risk individuals. BMC Cancer 8:214

56. Spurdle AB, Lakhani SR, Healey S, Parry S, Da Silva LM, Brinkworth R, Hopper JL, Brown MA, Babikyan D, Chenevix-Trench G, Tavtigian SV, Goldgar DE (2008) Clinical classification of BRCA1 and BRCA2 DNA sequence variants: the value of cytokeratin profiles and evolutionary analysis-a report from the kConFab Investigators. J Clin Oncol 26(10):1657-1663

57. Judkins T, Hendrickson BC, Deffenbaugh AM, Eliason K, Leclair B, Norton MJ, Ward BE, Pruss D, Scholl T (2005) Application of embryonic lethal or other obvious phenotypes to characterize the clinical significance of genetic variants found in trans with known deleterious mutations. Cancer Res 65(21):10096-10103

58. Claes K, Poppe B, Coene I, Paepe AD, Messiaen L (2004) BRCA1 and BRCA2 germline mutation spectrum and frequencies in Belgian breast/ovarian cancer families. Br J Cancer 90(6):1244-1251

59. Zhi X, Szabo C, Chopin S, Suter N, Wang QS, Ostrander EA, Sinilnikova OM, Lenoir GM, Goldgar D, Shi YR (2002) BRCA1 and BRCA2 sequence variants in Chinese breast cancer families. Hum Mutat 20(6):474

doi:10.1186/2193-1801-1-20

Cite this article as: Solano et al:: BRCA1 And BRCA2 analysis of

Argentinean breast/ovarian cancer patients selected for age and family history highlights a role for novel mutations of putative south-American origin. SpringerPlus 2012 1:20.

\section{Submit your manuscript to a SpringerOpen ${ }^{\circ}$ journal and benefit from:}

- Convenient online submission

- Rigorous peer review

- Immediate publication on acceptance

- Open access: articles freely available online

- High visibility within the field

- Retaining the copyright to your article 